\title{
Feeding habits of four species of mesopelagic fishes from the Northern Chilean
}

\author{
Eduardo Oliva A. ${ }^{1}$, Raúl Ulloa H. ${ }^{2}$ \& Jorge Bleck Z. ${ }^{1}$ \\ 1 Departamento de Ciencias del Mar, Universidad Arturo Prat, Casilla 121, Iquique, Chile \\ 2 Comunidad y Biodiversidad A.C. Blvd. Agua Marina 297. Col. Las Delicias, Guaymas, Sonora, México C.P. 85450; \\ rulloa@cobi.org.mx
}

Received 28-VIII-2001. Corrected 24-X-2002. Accepted 10-X-2003.

\begin{abstract}
The feeding habits of four species of mesopelagic fishes from northern Chile are described: Triphoturus mexicanus, Diogenichtys atlanticus, Vinciguerria lucetia and Cyclothone acclinidens. Samples were captured in September 1988 between $18^{\circ} 25^{\prime}$ and $19^{\circ} 09^{\prime} \mathrm{S}$ in the South West Pacific. The quantitative and qualitative analyses of the stomach content showed that the species have a zooplanktophagous opportunistic behavior, mainly predating on Crustaceans, especially on Copepods. The evaluation of the trophic spectrum and diversity of T. mexicanus and C. acclinidens suggests that these are nictoepipelagic species, while D. atlanticus and $V$. lucetia would be typical mesopelagic. Rev. Biol. Trop. 54(2): 613-622. Epub 2006 Jun 01.
\end{abstract}

Key words: stomach content analysis, mesopelagic fishes, Northern Chile.

Mid water fishes generally form dense groups, so they represent a good alternative for the production of fish flour. Gjosaeter and Kawaguchi (1980) estimate a standing stock of 51 millions of tons for the South West Pacific. Mesopelagic fishes from the South West Pacific have received some scientific attention, mainly in biogeographic studies (Parin et al. 1980, Acuña 1986, Kong and Meléndez 1991) and recently, Sielfeld et al. (1995) analyzed the distribution of these organisms and their relation to the deep dispersion layer.

The study of the food of a species by the analysis of the stomach content allows knowing its diet, determining its trophic place in the ecosystem and its possible relationships of dependence to other species. Moreover, the possible variations of its diet depending on certain parameters such as the depth where it is located, the time of the day and the season of the year can also be determined. This can give information about the position of an individual while eating as well as its function as a part of the biocoenosis (Amezaga 1988, Gual-Frau and Gallardo-Cabello 1988).

The study of the trophic relations on ichthyc populations begins in Chile in the decade of the 50's (Silva and Stuardo 1985). About this subject, there are a few publications that focusing mainly on species supporting traditional and industrial epipelagic fisheries (Moreno 1972, Chong et al. 1974, Martínez et al. 1990). However, there is no information about the feeding behavior of mesopelagic species in these waters, which have been considered to be a source for potential exploitation. The aim of this study is to describe the feeding habits of four mesopelagic species, which are abundant in front of the subtropical coasts of Northern Chile (18 $\left.25^{\prime} \mathrm{S}-19^{\circ} 09^{\prime} \mathrm{S}\right)$ during September 1988.

\section{MATERIALS AND METHODS}

Examined material belongs to the research programFAO-PNUCDCH/87/007“Application 
of new technologies for the capture of non traditional marine hydrobiologic resources on the Region I of Chile". Samples were colleted on 7-9 September 1988 at I Region of Chile $\left(18^{\circ} 25^{\prime}\right.$ and $\left.19^{\circ} 09^{\prime} \mathrm{S}\right)$ (Fig. 1), on board of the B/I "Carlos Porter".

Samples were collected by fishing at mid water with an IKMT (Isaac Kidd Midwater Trawl) trawl of $9.16 \mathrm{~m}^{2}$ at its open and 500 microns in its pocket. At each station, the gear was used at a velocity of 4 knot and an effective trawling time of $30 \mathrm{~min}$; the depths and times of each set are showed on table 1 . The collected material was fixed on board with formaldehyde at $5 \%$. The separation and recount of the number of individuals was done at the laboratory, sorting by species and station, measuring their Total Length (TL) with a precision of $0.01 \mathrm{~mm}$. Afterwards, the stomach content was obtained by dissection under stereoscopic microscope. The preys from zooplanktonic taxa were determined to the lowest taxonomic possible level.

The importance of the different prey taxa was evaluated by the methods of numeric analysis and the frequency of occurrence (Berg 1979, Hyslop 1980). The first is calculated by registering the number of individuals per taxon in each stomach and the total is expressed as a proportion ratio or more usually, as the

TABLE 1

Date, depth and start time for each haul at sampled stations

$\begin{array}{cccc}\text { Stations } & \text { Date } & \text { Depth }(\mathrm{m}) & \text { Start time (hr) } \\ 01 & 08 / 09 / 88 & 530 & 03: 30 \\ 02 & 08 / 09 / 88 & 643 & 07: 55 \\ 03 & 08 / 09 / 88 & 603 & 11: 55 \\ 04 & 08 / 09 / 88 & 513 & 15: 55 \\ 05 & 08 / 09 / 88 & 485 & 19: 55 \\ 06 & 09 / 09 / 88 & 450 & 02: 40 \\ 07 & 09 / 09 / 88 & 425 & 07: 00 \\ 08 & 09 / 09 / 88 & 200 & 11: 20 \\ 09 & 09 / 09 / 88 & 576 & 16: 55 \\ 10 & 09 / 09 / 88 & 450 & 19: 40\end{array}$

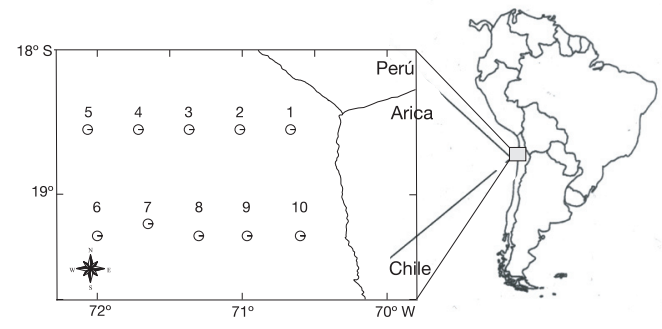

Fig. 1. Sample stations at study area.

percentage of the total of individuals in all feeding categories $(\mathrm{N})$, that is: $\% \mathrm{~N}=($ Number of samples of the prey / Total number of preys) * 100. The second method is referred to the percentage of fishes in a sample that contains a determined feeding category, that is:

$$
\mathrm{F}=(\mathrm{n} / \mathrm{NE}) * 100
$$

Where:

$\mathrm{F}=$ Frequency of occurrence of any food item. $\mathrm{n}=$ Number of stomachs that contain that food item.

$\mathrm{NE}=$ Total number of analyzed stomachs.

The registered values for this index are interpreted according to Yánez-Arancibia et al. (1976) as follows: $\mathrm{F}<0.10=$ Accidental food; $0.10<\mathrm{F}<0.50=$ Secondary food; $\mathrm{F}>0.50=$ Preferred food.

In addition, the specific trophic diversity was calculated for each of the species by the Shannon - Weaver index (Ludwig and Reynolds 1988). Before calculating the specific diversity, the rarefaction method by Sanders was used (Sanders 1968) to standardize the size of the sample.

\section{RESULTS}

A total of 3251 specimens were collected, and the number of analyzed organisms was different for each species due to the quantity of the obtained material. Examined material in global terms is showed in table 2 . 
TABLE 2

Number of individuals per taxon and number of analyzed organisms

\begin{tabular}{lccc}
\multicolumn{1}{c}{ TAXA } & $\begin{array}{c}\text { Number } \\
\text { of } \\
\text { individuals }\end{array}$ & $\begin{array}{c}\text { Number } \\
\text { of } \\
\text { analyzed }\end{array}$ & $\begin{array}{c}\text { \% Number } \\
\text { of analyzed }\end{array}$ \\
$\begin{array}{l}\text { Triphoturus } \\
\text { mexicanus }\end{array}$ & 509 & 261 & 51.28 \\
$\begin{array}{l}\text { Diogenichtys } \\
\text { atlanticus }\end{array}$ & 725 & 166 & 22.90 \\
$\begin{array}{l}\text { Vinciguerria } \\
\text { lucetia }\end{array}$ & 148 & 92 & 62.16 \\
$\begin{array}{l}\text { Cyclothone } \\
\text { acclinidens }\end{array}$ & 1869 & 324 & 17.34
\end{tabular}

\section{Numeric Analysis and Frequency of Occurrence for Species}

\section{Triphoturus mexicanus Gilbert, 1890}

The size range for the analyzed examples fluctuated between 19.90 and $61.60 \mathrm{~mm}$ TL. Registering a major frequency at 47 and 52 $\mathrm{mm}$ TL. From the 261 analyzed stomachs, $86.2 \%$ did not have any content, registering a total of 32-item prey. According to the numeric contribution, crustaceans constituted the most important trophic group with $81.29 \%$ of the prey, especially copepods that represented the $63.39 \%$ of the individuals (Table 3 ). Copepods were represented by 18 species, from which Centropages brachiatus (Dana) Brady, 1883 and Eucalanus sp. Dana 1852 highlighted by their percentages, as the most important species, with values of 19.07 and $6.13 \%$ respectively (Table 3).

According to the classification by YánezArancibia et al. (1976), copepods were registered as preferred food with a frequency of $73.56 \%$. As secondary item prey euphasiids, larvae, ostracods and crustaceans larvae were found (Table 4) while resting preys were classified as accidental.

\section{Diogenichtys atlanticus \\ Tanning, 1928}

The size range for the analyzed organisms was between 15.20 and $30.20 \mathrm{~mm}$ TL with a main frequency at 23 and $28 \mathrm{~mm}$ TL. From 166 analyzed stomachs, the $64.5 \%$ was found with content, registering a total of 16-item prey. According to its numeric contribution, the most abundant group was that of crustaceans with $77.2 \%$ of the prey and the copepods being more numerous, with $66.4 \%$. From the resting groups, larvae were important with $7.6 \%$ (Table 3). Copepods were represented by 5 species from which Corycaes sp. Dana, 1845 and Mecynocera clausi Thompson, 1888 stood out with 13.20 and $4.8 \%$ respectively (Table 3 ).

By the analysis of frequency of occurrence, copepods were classified as a preferred food with a frequency of appearance of $57.83 \%$, while the rest items were accidental (Table 4).

\section{Cyclothone acclinidens \\ Garman, 1899}

The size of this organism varied from 19.35 to $51.30 \mathrm{~mm}$ TL. Its major frequency was between 41 and $46 \mathrm{~mm}$ TL. $37.65 \%$ of a total of 324 stomachs had contents, registering a total of 22-item prey. The most important group was that of crustaceans ( $83.08 \%$ of the prey) and its most representative group were the copepods with $73.63 \%$ (Table 3). Copepods were represented by 11 species, from which Centropages brachiatus and Eucalanus sp. represented the 16.08 and $13.64 \%$ of the preys for this organism (Table 3).

For this species, the analysis of frequency of occurrence only showed secondary and accidental food, with copepods representing the first group (33.34\%) (Table 4).

\section{Vinciguerria lucetia \\ Garman, 1899}

The size range for this organism was between 12.00 and $48.80 \mathrm{~mm}$ TL, with a major 
TABLE 3

Numeric and percentage contribution of taxa found in the stomach content of the analyzed species

Species

\begin{tabular}{|c|c|c|c|c|c|c|c|c|}
\hline \multirow[b]{2}{*}{ TAXA } & \multicolumn{2}{|c|}{ T. mexicanus } & \multicolumn{2}{|c|}{ D. atlanticus } & \multicolumn{2}{|c|}{ V. lucetia } & \multicolumn{2}{|c|}{ C. acclinidens } \\
\hline & $\mathrm{n}$ & $\%$ & $\mathrm{n}$ & $\%$ & $\mathrm{n}$ & $\%$ & $\mathrm{n}$ & $\%$ \\
\hline PROTOZOA & 12 & 0.69 & & & & & 6 & 2.10 \\
\hline Order Radiolaria & 12 & 0.69 & & & & & 6 & 2.10 \\
\hline CNIDARIA & 1 & 0.06 & 3 & 1.20 & 1 & 0.52 & & \\
\hline Subclass Siphonophorae & & & 1 & 0.40 & & & & \\
\hline Subclass Hydromedusae & 1 & 0.06 & 2 & 0.80 & 1 & 0.52 & & \\
\hline ANNELIDA & 15 & 0.86 & 2 & 0.80 & 3 & 1.57 & & \\
\hline Class Polychaeta & 15 & 0.86 & 2 & 0.80 & 3 & 1.57 & & \\
\hline MOLLUSCA & 1 & 0.06 & & & & & & \\
\hline Order Pteropoda & 1 & 0.06 & & & & & & \\
\hline CHAETOGNATHA & 2 & 0.11 & & & & & 4 & 1.40 \\
\hline Sagitta sp. & 2 & 0.11 & & & & & 4 & 1.40 \\
\hline CRUSTACEA & 2601 & 81.29 & 372 & 77.20 & 312 & 90.56 & 455 & 83.08 \\
\hline Copepoda & 1117 & 63.99 & 166 & 66.40 & 138 & 72.25 & 208 & 73.63 \\
\hline Nannocalanus minor & 23 & 1.32 & & & & & & \\
\hline Neocalanus robustior & 5 & 0.29 & & & & & 1 & 0.35 \\
\hline Calanus sp. & 1 & 0.06 & 2 & 0.80 & & & & \\
\hline Undinula sp. & 4 & 0.23 & & & & & 2 & 0.70 \\
\hline Eucalanus sp. & 107 & 6.13 & & & 5 & 2.62 & 39 & 13.64 \\
\hline Paracalanus parvus & 5 & 0.29 & & & 6 & 3.14 & 2 & 0.70 \\
\hline Mecynocera clausi & 2 & 0.11 & 12 & 4.80 & & & 1 & 0.35 \\
\hline Euaetideus bradyi & 40 & 2.29 & 1 & 0.40 & & & 1 & 1.05 \\
\hline Euchirella bella & 1 & 0.06 & & & & & & \\
\hline Scolecithricella bradyi & 1 & 0.06 & & & 2 & 1.05 & 1 & 0.35 \\
\hline Temora discaudata & 2 & 0.11 & & & & & & \\
\hline Temora stylifera & 29 & 1.66 & & & & & 7 & 2.45 \\
\hline Temora sp. & 2 & 0.11 & & & & & & \\
\hline Centropages brachiatus & 333 & 19.07 & 3 & 1.20 & 13 & 6.81 & 46 & 16.28 \\
\hline Lucicutia flavicornis & 4 & 0.23 & & & & & 2 & 0.70 \\
\hline Augaptilus sp. & 1 & 0.06 & & & & & & \\
\hline Saphirina sp. & 2 & 0.11 & & & & & & \\
\hline Corycaeus sp. & 30 & 1.72 & 33 & 13.20 & 23 & 12.04 & & \\
\hline Unidentified & 515 & 29.50 & 37 & 14.80 & 26 & 13.61 & 73 & 25.52 \\
\hline Digested & 1 & 0.06 & 66 & 26.40 & 51 & 26.70 & 31 & 10.84 \\
\hline Copepodite & 9 & 0.52 & 12 & 4.80 & 12 & 6.28 & 2 & 0.70 \\
\hline
\end{tabular}


TABLE 3 (Continued)

Numeric and percentage contribution of taxa found in the stomach content of the analyzed species

\begin{tabular}{|c|c|c|c|c|c|c|c|c|}
\hline \multirow{3}{*}{ TAXA } & \multicolumn{8}{|c|}{ Species } \\
\hline & \multicolumn{2}{|c|}{ T. mexicanus } & \multicolumn{2}{|c|}{ D. atlanticus } & \multicolumn{2}{|c|}{ V. lucetia } & \multicolumn{2}{|c|}{ C. acclinidens } \\
\hline & $\mathrm{n}$ & $\%$ & $\mathrm{n}$ & $\%$ & $\mathrm{n}$ & $\%$ & $\mathrm{n}$ & $\%$ \\
\hline Order Amphipoda & 6 & 0.34 & & & & & & \\
\hline Suborder Hyperiidea & 6 & 0.34 & & & & & & \\
\hline Order Ostracoda & 52 & 2.98 & 12 & 4.80 & 26 & 13.61 & 10 & 3.50 \\
\hline Order Cladocera & 20 & 1.15 & & & 1 & 0.52 & & \\
\hline Order Euphausida & 165 & 9.45 & 2 & 0.80 & 7 & 3.66 & 5 & 1.75 \\
\hline Order Decapoda & 59 & 3.38 & 13 & 5.20 & 1 & 0.52 & 12 & 4.20 \\
\hline Larvae & 59 & 3.38 & 7 & 2.80 & & & 3 & 1.05 \\
\hline Undetermined crustaceans & & & 6 & 2.40 & 1 & 0.52 & 9 & 3.15 \\
\hline TUNICATA & 120 & 6.87 & 19 & 7.60 & 9 & 4.71 & 21 & 7.34 \\
\hline \multicolumn{9}{|l|}{ Order Appendiculata } \\
\hline Oikopleura sp. & 120 & 6.87 & 19 & 7.60 & 9 & 4.71 & 21 & 7.34 \\
\hline VERTEBRATA & 176 & 10.08 & 33 & 13.20 & 5 & 2.62 & 16 & 5.60 \\
\hline Eggs fish & 5 & 0.29 & 6 & 2.40 & 3 & 1.57 & 2 & 0.70 \\
\hline Undetermined & 171 & 9.79 & 27 & 10.80 & 2 & 1.05 & 14 & 4.90 \\
\hline
\end{tabular}

TABLE 4

Frequency of occurrence of the prey taxa for the analyzed species

Species

TAXA T. mexicanus D. atlanticus V.lucetia $\quad$ C. acclinidens

\section{PROTOZOA}

Order Radiolaria

\section{CNIDARIA}

Subclass Siphonophorae

0.6

Subclass Hydromedusae

0.38

1.2

1.09

\section{ANNELIDA}

Class Polychaeta

0.6

MOLLUSCA

Order Pteropoda

0.38

\section{CHAETOGNATHA}

Sagitta sp.

\section{CRUSTACEA}

Copepoda
Nannocalanus minor
Neocalanus robustior

73.56

57.83

46.74

33.34 
TABLE 4 (Continued)

Frequency of occurrence of the prey taxa for the analyzed species

Species
TAXA
T. mexicanus
D. atlanticus
V. lucetia
C. acclinidens

Calanus sp.

0.38

0.6

Undinula $\mathrm{sp.}$

1.15

Eucalanus sp.

24.14

5.43

6.17

Paracalanus parvus

2.3

3.26

0.31

Mecynocera clausi

0.77

3.01

0.31

Euaetideus bradyi

0.05

0.6

0.93

Euchirella bella

0.38

Scolecithricella bradyi

0.38

2.17

0.31

Temora discaudata

0.38

Temora stylifera

0.05

0.93

Temora sp.

0.38

Centropages brachiatus

41

1.81

6.52

4.01

Lucicutia flavicornis

1.53

0.62

Augaptilus sp.

0.38

Saphirina sp.

0.77

Corycaeus sp.

5.36

12.05

4.35

Unidentified

60.15

18.07

28.26

13.58

Digested

5.36

19.28

6.52

0.31

Copepodite

5.36

19.28

0.31

6.52

Order Amphipoda

Suborder Hyperiidea

1.53

Order Ostracoda

14.18

6.63

20.65

Order Cladocera

3.45

1.09

34.1

2.41

7.61

2.16

Order Decapoda

Larvae

13.79

3.01

0.93

Undetermined crustaceans

6.51

1.2

1.09

\section{TUNICATA}

Order Appendiculata

19.54

7.23

7.61

Oikopleura sp.

19.54

7.23

7.61

3.09

VERTEBRATA

Eggs fish

Undetermined
1.53

23.37
1.2

3.26

2.17
0.62

3.09 
frequency at 29 and $34 \mathrm{~mm}$ TL. From the 92 analyzed stomachs, the $63.04 \%$ had content with a total of 16 -item prey. The most important trophic group was that of crustaceans with $90.56 \%$ of the prey, and copepods represented the $72.25 \%$. Copepods had 5 species from which Corycaeus sp. and Centropages brachiatus were the most important with values of 12.04 and $6.81 \%$ (Table 3).

Preys were classified as secondary or accidental food. The first group was formed by copepods and ostracods with frequencies of occurrence of 46.74 and $20.65 \%$ respectively, while for the second classification, the rest taxa were included (Table 4).

Trophic diversity. The trophic spectrum for each species has been considered as the number of taxonomic categories eaten by a particular predator. For its calculus the undetermined group was omitted for it can contain more than one taxonomic group.

The species with a wider trophic spectrum were T. mexicanus and C. acclinidens that surpass $D$. atlanticus and $V$. lucetia in the number of taxonomic groups predated in the area and sample locations. The major width of the trophic spectrum for the indicated species obeys to the major number of accidental or rare preys registered in their stomach content (Table 5).

T. mexicanus and C. acclinidens, exhibited the major trophic diversity with respect to total area and stations sampled. In time sense, the same species showed a major trophic diversity at night, which could imply a nocturnal behavior. D. atlanticus and V. lucetia showed a major trophic diversity at day; however, the lack of collections or samples with adequate densities at night hours, did not allow to evaluate their feeding behavior on a daily cycle (Table 6).

\section{DISCUSSION}

The study of the feeding habits of the analyzed species, revealed a zooplanktophagous behavior, preying mainly on crustaceans, especially on calanoid copepods. This is in agreement with the reports the different mesopelagic families and species reported for other oceans (Tyler and Pearcy 1975, Clarke 1978, Holton 1969, Pearcy et al. 1979, Young and Blaber 1986, Palma 1990).

The diet for T. mexicanus and D. atlanticus coincides with that reported by Parín (1968) for this family, which is constituted mainly by calonoid copepods, euphasiids, amphipods and decapods larvae. Even though appendicularians registered percentages lower than $10 \%$, its numeric contribution has to be pointed out since they are rich in energetic content, although they are considered as accidental or accessory items (Fenaux 1985). To this respect, Aravena (1999) registered high densities for this group in planktonic samples from Northern Chilean waters.

At specific level, the diet of T. mexicanus is similar to that of T. nigrescens (Brauer, 1904) in

TABLE 5

Standardized values by the method of rarefaction and trophic diversity

$\begin{array}{lcccc} & \text { T. mexicanus } & \text { D. atlanticus } & \text { V. lucetia } & \text { C. acclinidens } \\ \text { Number of individuals } & 225 & 107 & 58 & 122 \\ \text { Total number of preys } & 1737 & 223 & 189 & 272 \\ \text { Total Taxa prey } & 33 & 16 & 15 & 21 \\ \text { Rarefacción (N of preys) } & 20 & 16 & 15 & 21 \\ \text { Total Diversity } & 0.297 & 0.248 & 0.261 & 0.301 \\ \text { Average Diversity } & 1.816 & 1.873 & 1.028 & 1.596 \\ \text { Standard Diversity } & 0.312 & 0.494 & 0.653 & 0.33\end{array}$


waters of Hawaii, which feeds mainly on copepods and euphasiids (Clarke 1978). Besides, the composition of food for $C$. acclinidens agrees to that observed in other gnostomatids such as Gnostoma atlanticum Norman, 1930, G. elongatum Gunther, 1878 and Maurolicus melleri Gmelin, 1788 (Clarke 1978, Young and Blaber 1986) whose preferred trophic group is that of copepods. Moreover, Palma (1990) observed, by the analysis of the stomach content of Cyclothone braueri Jespersen and Taning, 1926, that the $80 \%$ of the content were copepods, highlighting Pleuromamma gracilis (Claus, 1843) and Euchaeta marina (Prestandrea, 1833). Also, the observed diet of $V$. lucetia is similar to that of $V$. nimbaria Jordan and Williams, 1896 which inhabits the waters of Hawaii and the Equatorial Atlantic (Clarke 1978, Shevchenko 1996), feeding also on copepods, euphasiids and ostracods.

The dominance of copepods, expressed as the preferred trophic group, would be an expression of the environmental offer for food; yet copepods is the dominant taxonomic group in waters of Northern Chile (Mujica and Rojas 1985). Furthermore, the dominance of Centropages brachiatus in the digestive apparatus of the analyzed species coincides with the importance of this species in the plankton of these waters (González and Marín 1998).
The major abundance of copepods in the digestive apparatus of all analyzed species would agree to the expressed by Platt and Denman (1978), who indicated that when the size range of the preys was small, the predator did not selected the prey according to its size due to their abundance in the environment. Moreover, these results would confirm the theory of Clark (1985) who indicated that the presence of an abundant prey or few preys in the stomach of a predator indicates that fishes prey on the mass of planktonic organisms without selecting their preys. This author also points out that the presence of one or few planktonic species in the stomach of the predator, is the result of a simple encounter between the predator and the prey; in other words, fishes prey on a mass of plankton and do not select small individual organisms.

The similarity in the dominance of the zooplankton in the digestive apparatus of the analyzed fishes, suggests that they are opportunistic predators, feeding on the plankton of the environment of a particular area. Yet, mid water oceanic fishes are generally opportunistic consumers, migrating to the surface at night to feed (Hopkins and Baird 1975, Clarke 1978, Kinzer and Schulz 1985, Young and Blaber 1986, Shevchenko 1996).

TABLE 6

Specific diversity values for each of the species by station and time

$\begin{array}{cccccc}\text { Station } & \text { Time } & \text { T. mexicanus } & \text { D. atlanticus } & \text { V. lucetia } & \text { C. acclinidens } \\ 1 & 03: 30 & 1.535 & - & 0.025 & 1.368 \\ 2 & 07: 55 & 1.451 & 1.431 & 0.026 & 1.006 \\ 3 & 11: 55 & 1.454 & 1.686 & - & 1.958 \\ 4 & 15: 55 & 1.595 & 1.934 & - & 1.012 \\ 5 & 19: 55 & 2.133 & 1.818 & - & 1.759 \\ 6 & 02: 40 & 2.403 & - & 0.563 & 1.918 \\ 7 & 07: 00 & 1.848 & - & - & 1.986 \\ 8 & 11: 20 & 1.978 & 1.976 & 1.665 & 1.46 \\ 9 & 16: 55 & 1.823 & 1.831 & 2.051 & 1.609 \\ 10 & 19: 40 & 1.936 & 0.563 & 1.839 & 1.888\end{array}$


The results of trophic diversity for the analyzed species showed that these are considered as general feeders, tending to be euriphagic, since according to Berg (1979), "high values" of diversity reveal the euriphagic character of the predators. In the same way, prey items reveal that the analyzed species are third order carnivorous, having preference for crustaceans, especially copepods. The qualitative and quantitative characterization of the fishes' feeding habits is, in general, a function of the size of the analyzed samples, especially when the fishes are plankton eaters so the food offer is variable in function of time and space.

Gorelova (1977) postulates the existence of two ecological kinds of mictophyds. The nictoepipelagic rise regularly to the surface during night, and the mesopelagic, whose migrations do not exceed the limits of the mesopelagic region. These results confirm the fact that nictoepipelagic fishes exhibit a broader trophic spectrum while the food for the mesopelagic group is more homogeneous. The evaluation of the trophic spectrum of the studied species suggests that $T$. mexicanus and $C$. acclinidens would be epipelagic species, whereas $D$. atlanticus and $V$. lucetia would be mesopelagic. Nevertheless, the low captures for the last two species at night times did not allow concluding if they have migrations to the surface.

Finally, the characterization of the feeding habits for the studied species is valid for the area and time of the year considered, since the diets are modified by seasonal variations in zooplankton (Hopkins and Baird 1977, Gjosaeter 1981a,b).

\section{RESUMEN}

Se describen los hábitos alimenticios de cuatro especies de peces mesopelágicos del norte de Chile: Triphoturus mexicanus, Diogenichtys atlanticus, Vinciguerria lucetia and Cyclothone acclinidens. Las muestras fueron capturadas en setiembre de 1988 entre $18^{\circ} 25^{\prime}$ y $19^{\circ} 09^{\prime} \mathrm{S}$ en el Pacífico suroeste. El análisis cualitativo y cuantitativo del contenido estomacal mostró que las especies tienen un comportamiento zooplantofago oportunista, depredando principalmente crustáceos, especialmente copépodos. La evaluación del espectro trófico y diversidad de T. mexicanus y $C$. acclinidens sugiere que estas son especies nictoepipelágicas, mientras que $D$. alanticus y $V$. lucetia serían mesopelágicas típicas.

Palabras clave: contenidos estomacales, peces mesopelágicos, norte, Chile.

\section{REFERENCES}

Acuña, E. 1986. El recurso mictófidos (Pisces Myctophidae): antecedentes en aguas chilenas y marco de referencia para su investigación, p. 315-339. In P. Arana (ed.). La Pesca en Chile. Escuela de Ciencias del Mar, Valparaíso, Chile.

Amezaga, R. 1988. Análisis de contenidos estomacales en peces. Revisión bibliográfica de los objetivos y la metodología. Inf. Téc. Inst. Esp. Oceanogr. 63: 1-74.

Aravena, G. 1999. Composición, distribución y abundancia de las apendicularias en relación con las características oceanográficas de la zona norte de Chile (18²0' S$\left.31^{\circ} 00^{\prime} \mathrm{S}\right)$. Tesis para optar al Título de Biólogo Marino, Univ. Católica del Norte, Coquimbo, Chile. 100 p.

Berg, J. 1979. Discussion of methods of investigating the food of fishes, with reference to a preliminary study of the prey Gobisculus flavescens (Gobidae). Mar. Biol. 50: 263-273.

Chong, J., D. López \& R. Ahumada. 1974. Algunos alcances sobre la alimentación del Chancharro (Helicolenus lengerichi Norman, 1937) en el sur de Chile. Bol. Soc. Biol. Concepción, 38: 147-154.

Clarke, T.A. 1978. Diet feeding patterns of 16 species of mesopelagic fishes from Hawaiian waters. Fish. Bull. U.S. 76: 495-513.

Fenaux, R. 1985. Rhythm of secretion of Oikopleurid houses. Bull. Mar. Sci. 37: 498-503.

Gual-Frau, A. \& M. Gallardo-Cabello. 1988. Análisis de la frecuencia y hábitos alimenticios de la "Cigala" Nephrops norvegicus (Linneo, 1758) en el Mediterráneo Occidental (Crustacea: Nephropsidae). An. Inst. Cienc. del Mar y Limnol. Univ. Nal. Autón. México. 15(1): 151-166.

Gjosaeter, J. \& K. Kawaguchi. 1980. A review of the world resources of mesopelagic fish. FAO. Fish. Tech. Pap. 193: 151 .

Gjosaeter, J. 1981a. Life history and ecology of Maurolicus muelleri (Gonostomidae) in Norwegian waters. Fiskdir. Skr. (Ser. Havunders). 17: 109-131.

Gjosaeter, J. 1981b. Life history and ecology of the mycthophic fish Notoscopelus elongatus Kroeyeri from 
northeast Atlantic. Fiskdir. Skr. (Ser. Havunders). 17: $133-152$

Gorelova, T. 1977. Some characteristics of the nutrition of the young of nictoepipelagic and mesopelagic lantern fish (Pisces, Myctophidae) in the Equatorial Pacific Ocean. J. Ichtyol. 23(3): 106-113.

Gonzalez, A. \& V. Marín. 1998. Distribution an life cycle of Calanus chilensis and Centropages brachiatus (Copepoda) in Chilean waters: a GIS approach. Mar. Ecol. Prog Ser. 165: 109-117.

Holton, A.A. 1969. Feeding behaviour of a vertically migrating lanterfish. Pacif. Sci. 23: 325-331.

Hopkins, T. L. \& R. C. Baird. 1975. Net feeding in mesopelagic fishes. Fish. Bull. U.S. 73: 908-914.

Hopkins, T. \& R. Baird. 1977. Aspects of the feeding ecology of oceanic midwaters fishes, p. 325-360. In R. Anderson \& B. Zahuranec (eds.). Oceanic Sound Scattering Prediction. Plenum, New York.

Hyslop, E. 1980. Stomach contents analysis. A review of meth. and their appl. J. Fish. Biol. 17: 411-429.

Kinzer, J. \& K. Schulz. 1985. Vertical distribution and feeding patterns of midwaters fish in the Central Equatorial Atlantic. I. Mycthophidae. Mar. Biol. 85: 313-322.

Kong, I. \& R. Meléndez. 1991. Estudio taxonómico y sistemático de la ictiofauna de aguas profundas cap-

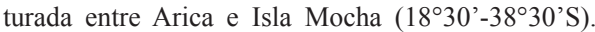
Estud. Oceanol. 10: 1-81.

Ludwig, J. \& J. Reynolds. 1988. Statistical Ecology. A primer on methods and computing. Wiley, New York. 335 p.

Martínez, C., L. Caballero, G. Böhm, A. Torres, R. Gili, V. Bocic, P. Barría \& R. Serra. 1990. Diagnóstico de las principales pesquerías nacionales pelágicas zona norte (I-IV Región) 1989. Estado de situación del recurso. Convenio CORFO-IFOP. Inst. Fom. Pesq. Santiago, Chile. (AP 90/10). 119 p.

Moreno, C. 1972. Nicho alimentario de la "vieja negra" (Graus nigra Philippi). (Osteichthyes, Labridae). Not. Men. Mus. Nac. Hist. Nat. Chile. 16(186): 5-6.

Mujica, A. \& O. Rojas. 1985. Composición y abundancia del zooplancton del norte de Chile. Crucero MARCHILE XV-ERFEN VI, Diciembre 1983. Cienc. Tec. Mar. 9: 31-52.
Palma, S. 1990. Ecologie alimentaire de Cyclothone braueri Jespersen et Taning, 1926 (Gonostomatidae) en mer Ligure, Méditerranée occidentale. J. Plankton Res. 12: 519-534.

Parín, N. 1968. Ichtyofauna of epipelagic zone. Israel Program for Scientic Translation, Tel Avid. pp. 205.

Parín, N., G. Golovan, N. Pakhorukov, Y. Sazonov \& Y. Sherbachev. 1980. Fishes from the Nazca and Sala y Gomez underwater ridges collected in the cruise of R/V "Ikhtiandr", p. 5-18. In N.V. Parín (ed.). Fishes of the open ocean. Sea Acad. Inst. of Oceanol., Moscow.

Pearcy, W. G., H. V. Lorz \& W. Peterson. 1979. Comparison of the feeding habits of migratory and non-migratory Stenobrachius leucopsarus, Myctophidae. Mar. Biol. 51: $1-8$.

Platt, P. \& V. Denman. 1978. Mesopelagic fish. John Wiley, New York, USA. 355 p.

Sanders, H. 1968. Marine benthic diversity: a comparative study. Am. Nat. 102: 925-968.

Shevchenko, N.F. 1996. Feeding of Vinciguerria nimbaria (Gonostomatidae) in active dynamic zones of the east equatorial Atlantic. Voprosy Ikhtiol. 36: 552-554.

Sielfeld, W., M. Vargas. \& R. Fuenzalida. 1995. Peces mesopelágicos frente a la costa norte de Chile $\left(18^{\circ} 25^{\prime}\right.$ $21^{\circ} 47^{\prime}$ S). Invest. Mar. Valparaíso. 23: 83-97.

Silva, M. \& J. Stuardo. 1985. Alimentación y relaciones tróficas generales entre algunos peces demersales y el bentos de Bahía Coliumo (Prov. de Concepción, Chile). Gayana, Zool. 49(3-4): 77-102.

Tyler, H.R. \& W.G. Pearcy. 1975. The feeding of three species of lantern fishes (Family Myctophidae) off Oregon. USA. Mar. Biol. 32: 7-11.

Yañez-Arancibia, A., J. Curiel-Gómez \& V. Yañez. 1976. Prospección biológica y ecológica del bagre marino Galeichthys caerulescens (Gunther) en el sistema lagunar costero de Guerrero, México (Pisces: Ariidae). An. Inst. Cienc. del Mar y Limnol. Univ. Nal. Autón. México. 3(1): 125-180.

Young, J. W. \& S. J. M. Blaber. 1986. Feeding ecology of three species of midwater fishes associated with the continental slope of eastern Tasmania, Australia. Mar. Biol. 93: 147-156. 